\title{
MIKROORGANISME DALAM PANGAN
}

\author{
Ratih Yuniastri' ${ }^{1}$, Ismawati, Rika Diananing Putri \\ Prodi Teknologi Hasil Pertanian, Fakultas Pertanian, Universitas Wiraraja Sumenep, \\ 1) email: ratihyuniastri@wiraraja.ac.id
}

\begin{abstract}
ABSTRAK
Pengolahan bahan mentah menjadi bahan setengah jadi maupun bahan jadi bertujuan selain untuk memperpanjang umur simpan juga menambah nilai ekonomis bahan serta menjaga kandungan nutrisi yang terkandung didalamnya. Terdapat banyak jenis teknik pengolahan pangan yang dapat diterapkan, misalnya pengolahan pada suhu lingkungan, pengolahan dengan menggunakan panas dan pengolahan dengan penghilangan panas. Mikroorganisme memiliki peran penting dalam prosesnya, baik yang sifatnya dapat menambah mutu produk pangan hingga yang bersifat patogen. Terdapat beberapa jenis mikroorganisme khususnya dalam produk olahan suhu tinggi, olahan suhu rendah dan olahan fermentasi. Secara garis besar, mikroorganisme ini dibagi menjadi 2 kelompok, yaitu bakteri dan spora. Spora memiliki ketahanan yang lebih besar daripada bakteri. Clostridium botulinum dan Bacillus cereus merupakan mikroorganisme yang dijumpai pada ketiga jenis pengolahan yang dipilih. Melalui prosedur cara pengolahan yang baik sesuai standar HACCP akan dapat mengurangi terjadinya cemaran mikroorganisme patogen dan tercapainya keamanan pangan.

Kata Kunci: mikroorganisme, fermentasi, suhu tinggi, suhu rendah.
\end{abstract}

\section{PENDAHULUAN}

Pengolahan bahan mentah menjadi bahan setengah jadi maupun bahan jadi bertujuan selain untuk memperpanjang umur simpan juga menambah nilai ekonomis bahan serta menjaga kandungan nutrisi yang terkandung didalamnya. Beberapa jenis pengolahan yang dipilih terkadang dapat menyebabkan terjadinya denaturasi bahkan pengurangan nutrisi yang terkandung. Perubahan ini akan berakibat terhadap kandungan gizi dan kualitas organoleptik produk pangan yang dihasilkan, misalnya terjadinya perubahan warna, rasa, aroma bahkan kenampakan fisiknya.

Terdapat banyak jenis teknik pengolahan pangan yang dapat diterapkan, pemilihannya didasarkan sifat bahan pangan yang akan diolah dan tujuan akhir yang hendak dicapai oleh produsen. Beberapa teknik pengolahan yang dapat digunakan yaitu pengolahan pada suhu lingkungan, pengolahan dengan menggunakan panas dan pengolahan dengan penghilangan panas (Fellows, 2016). Beberapa jenis pengolahan tersebut memanfaatkan mikroorganisme dalam prosesnya, misalnya pada pengolahan menggunakan suhu lingkungan dengan cara fermentasi.

Mikroorganisme dalam pangan memiliki peranan penting, terutama pada proses pengolahan bahan mentah menjadi produk setengah jadi dan produk jadi dikarenakan enzim yang terdapat dalam mikroorganisme tersebut. Banyak manfaat yang bisa kita peroleh dari pemanfaatan mikroorganisme ini, diantaranya sebagai starter produk pangan hingga fungsinya yang mampu menghambat kerusakan dan pembusukan bahan pangan. Namun, selain manfaat tersebut, mikroorganisme juga memiliki andil dalam terjadinya kerusakan dan proses pembusukan bahan pangan. Beberapa proses pengolahan yang kurang tepat malah dapat menimbulkan tumbuhnya mikroorganisme patogen. Mikroorganisme ini selanjutnya menyebabkan terjadinya cemaran mikroba dalam pangan.

Faktor hiegene dan sanitasi yang baik menjadi syarat untuk menghindari terjadinya cemaran mikroorganisme selama proses pengolahan pangan (Wulandari dkk, 2017). Secara pendekatan 


\section{HACCP (Hazard Analysis Critical} Control Point), menjelaskan bahwa bahaya keamanan pangan dapat dicegah dengan menerapkan pengendalian sehingga resiko dapat dikurangi dan bahkan diminimalkan sampai tingkat yang dapat diterima, yaitu melalui pengendalian kedua faktor, hiegene dan sanitasi.Tulisan ini bertujuan untuk mengulas jenis mikroorganisme yang sering terdapat dalam pangan pada beberapa jenis pengolahan, khususnya pada pangan olahan suhu tinggi, pangan olahan beku dan pangan olahan fermentasi. Hal ini menjadi sangat penting sebagai informasi yang dapat menambah pemahaman dan meningkatkan kesadaran tentang pentingnya proses pengolahan yang benar untuk menghasilkan produk pangan dengan kandungan nutrisi yang baik dan kandungan zat yang masih dapat diterima.

\section{METODE PENELITIAN}

Penelitian ini merupakan penelitian deskriptif, dilakukan menggunakan metode review literature atau penelusuran pustaka, berupa buku textbook, paper dari jurnal ilmiah dan proceedings, tesis dan disertasi serta majalah ilmiah dan laporan. Literatur dikumpulkan kemudian dibuat rangkuman selanjutnya dilakukan analisis dan sintesis secara mendalam terhadap paper yang ditinjau.

\section{HASIL DAN PEMBAHASAN}

\section{Mikroorganisme dalam pangan olahan suhu tinggi}

Proses pengolahan pangan menggunakan suhu tinggi bertujuan untuk mengurangi kadar air dalam pangan, fungsinya untuk membunuh mikroorganisme dalam pangan sehingga dapat memperpanjang umur simpannya. Dua hal penting dalam pengolahan ini adalah keamanan pangan dan kualitas pangan yang dihasilkan. Proses inaktivasi mikroorganisme patogen dalam produk pangan masih menjadi perhatian utama kesehatan masyarakat.

Panas spesifik, konduktivitas termal dan difusivitas termal adalah tiga sifat termal yang penting dalam makanan (Fellows, 2016). Pada prosesnya, pengolahan dengan panas menggunakan penghantar panas, pemilihannya didasarkan pada sifat bahan pangan yang akan diproses dan derajat pemanasan yang dibutuhkan. Pada pengolahan menggunakan panas, terjadi denaturasi protein yang berakibat rusaknya enzim dan proses metabolisme yang dikendalikan enzim mikroorganisme. Kondisi panas (suhu dan waktu pemanasan) disesuaikan dengan jenis mikroorganisme, sehingga umumnya dilakukan kombinasi waktu-suhu yang spesifik dalam setiap tahap pengolahannya. Fungsinya juga meminimalisir terjadinya destruksi terhadap banyak vitamin, senyawa aroma dan zat warna yang terdapat dalam bahan pangan tersebut, sehingga sifat nutrisi dan sensori pangan dapat dipertahankan.

Ketahanan panas mikroorganisme dipengaruhi oleh beberapa faktor diantaranya jenis mikroorganisme, kondisi inkubasi selama pertumbuhan sel atau pembentukan spora (meliputi suhu, usia kultur dan media kultur) dan kondisi selama perlakuan panas (misalnya $\mathrm{pH}$ bahan pangan, aktivitas air, komposisi bahan, media pertumbuhan dan kondisi inkubasi yang digunakan). Bentuk spora umumnya jauh lebih tahan panas dibandingkan dengan sel vegetative (Fellows, 2016). Ini ditunjukkan dengan adanya perbedaan nilai-z pada spora dan sel vegetative. Spora memiliki nilai-z sekitar $10^{\circ} \mathrm{C}$ dan sel vegetative memiliki nilai-z antara $4^{\circ} \mathrm{C}$ dan $8^{\circ} \mathrm{C}$. Semakin rendah nilai-z menunjukkan bahwa reaksi inaktivasi sangat sensitif terhadap suhu (Brennan, 2006).

Mikroorganisme jenis sel vegetative yang rentan muncul pada bahan olahan 
suhu tinggi (panas) adalah Bacillus subtilis, Campylobacter jejuni, Clostridium sporogenes, E. coli $\mathrm{O} 157: \mathrm{H} 8$, Lysteria monogenes, Staphylococcus Aureus, Salmonella senftenberg, Vibrio cholera, Vibrio parahaemolyticus, Yersinia enterocolitica dengan nilai-D berada di kisaran 0-2,5; sedangkan dengan nilai-D di kisaran 2,2-6,6 meliputi Aeromonas hydrophila, Bacillus stearothermophillus, Bacillus cereus, Clostridium thermosaccharolyticum, Escheria coli O111:B4, E. coli O157:H7, Staphylococcus aureus, Salmonella typhimurium. Jenis sel vegetative dengan nilai-D besar yaitu Listeria monocytogenes pada produk daging, Salmonella senftenberg dan Salmonella typhinium pada produk susu coklat, dan Vibrio parahaemolyticus.

Mikroorganisme jenis spora yang terdapat pada produk olahan suhu tinggi yaitu Clostridium botulinum 62A dengan nilai-D 0,61-2,48 dan Bacillus cereus, Bacillus subtilis, Clostridium botulinum B, Clostridium botulinum E, Clostridium perfringens dengan nilai-D hingga mencapai 30,2.

Perbedaan ketahanan panas yang dimiliki mikroorganisme, yang ditunjukkan dengan nilai-D, mengharuskan perlakuan berbeda untuk setiap jenisnya. Campylobacter, Salmonella, Lysteria dan E. coli 0157 dapat diinaktivasi dengan pasteurisasi. Bacillus cereus masih dapat bertahan pada kondisi pasteurisasi karena memiliki ketahanan panas yang lebih besar dan bahkan mampu tumbuh kembali pada suhu rendah. Jenis spora yang memiliki ketahanan panas yang besar adalah Clostridium botulinum, merupakan bakteri pathogen bawaan dalam makanan, sangat penting untuk diinaktivasi karena dapat menyebabkan proses pembusukan makanan (Brennan, 2006). Jamur, ragi, bakteri penghasil gas, dan bakteri souring termasuk dalam jenis spora ini, salah satu contohnya jamur Altenaria, Botrytis, Diplodia, dan bakteri Ervinia yang umumnya terdapat dalam buah dan sayur (Rawat, 2015).

Salmonella, Shigella, Bacillus cereus, dan $S$. aureus merupakan bakteri pathogen yang umumnya mencemari produk pangan susu, sedangkan pada daging umumnya Salmonella sp., E. coli, Coliform, Staphylococcus sp., dan Pseudomonas (Gustiani, 2009).

\section{Mikroorganisme dalam pangan olahan beku}

Pengolahan bahan pangan dengan penghilangan panas atau dengan penurunan suhu pangan memiliki keuntungan dapat mempertahankan karakteristik sensori dan nilai gizi sehingga dapat dihasilkan produk yang berkualitas dan bernilai tinggi (Fellows, 2016). Pendinginan disini mencakup proses pendinginan dan pembekuan. Keduanya dibedakan berdasarkan suhu akhir dari bahan yang akan didinginkan dan jenis penghilangan panas. Adanya pendinginan akan mengakibatkan terjadinya perubahan kecil pada karakteristik sensori dan nilai gizi produk pangan. Pendinginan digunakan pada teknik pengolahan ini, fungsinya untuk memperpanjang umur simpan bahan pangan, dimana suhu pangan dijaga pada $1^{\circ} \mathrm{C}$ dan $8^{\circ} \mathrm{C}$. Suhu ini dipilih karena mampu mengurangi laju perubahan biokimia dan mikrobiologis dalam pangan (Brennan, 2006). Suhu yang rendah ini mampu menginaktivasi bakteri karena membrane sel bakteri berada dalam kondisi permeabel yang menyebabkan banyak protein mengalir keluar dari sel bakteri (Haberl-Meglic et. al, 2016).

Dua metode pendinginan pangan yang sering digunakan yaitu kompresi-uap mekanik dan kriogenik. Empat komponen dasar dalam pendingin kompresi-uap mekanik, yaitu evaporator, kompresor, kondensor, dan katup ekspansi. Zat 
pendingin akan bersirkulasi pada keempat komponen tersebut dengan tekanan, terjadinya perubahan wujud dari cair ke gas dan kembali lagi menjadi cair dengan perubahan entalpi pada tiap tahapnya. Pada pendinginan kriogenik, zat pendingin (kriogen) yang digunakan umumnya $\mathrm{CO}_{2}$ padat, $\mathrm{CO}_{2}$ cair atau nitrogen cair (Fellows, 2016).

Reaksi biokimia dalam pangan segar dihambat dengan adanya pendinginan menyebabkan adanya pengurangan laju perubahan enzimatik dan memperlambat laju respirasi dan penuaan pangan segar. Pendinginan dapat mencegah pertumbuhan banyak mikroorganisme mesofilik dan semua mikroorganisme termofilik yang memiliki minimum growth temperature (MGT) $5-10$ dan $30-40^{\circ} \mathrm{C}$ secara berturut-turut. Hal ini tidak berlaku pada mikroorganisme psikotrof dan psikofil yang memiliki MGT $0-5^{\circ} \mathrm{C}$. Sebagian besar mikroorganisme jenis ini terdapat pada ikan perairan dalam. Kondisi makanan yang disimpan di bawah MGT mikroorganisme dapat menyebabkan sel dari mikroorganisme dapat mati secara perlahan, namun jika suhu meningkat maka sel tersebut mampu bertahan hidup dan melanjutkan pertumbuhannya (Fellows, 2016). Reaksi kimia dalam pangan berlangsung pada laju yang sangat rendah dan pertumbuhan mikroorganisme secara menyeluruh dihentikan pada titik pengurangan populasi mikroorganisme terendah melalui proses pendinginan (Brennan, 2006). Pemilihan suhu pendinginan didasarkan pada jenis mikroorganisme yang umumnya terdapat dalam bahan pangan yang akan didinginkan.

Mikroorganisme perusak yang paling umum dalam pangan olahan dingin adalah bakteri Gram negative. Bakteri ini memiliki MGT $0-3^{\circ} \mathrm{C}$ dan memiliki pertumbuhan yang baik pada suhu $5-10^{\circ} \mathrm{C}$ untuk beberapa jenisnya. Yang termasuk bakteri ini adalah Pseudomonas spp.,
Aeromonas spp., Acinetobacter spp., dan Flavobacterium spp. Air merupakan media terjadinya kontaminasi bahan pangan untuk bakteri ini. Kondisi peralatan atau permukaan yang kurang dibersihkan dengan baik merupakan media kontaminasi yang disukai bakteri ini. Dampaknya akan menimbulkan pigmen, lendir, rasa atau bau yang tidak enak hingga menyebabkan kebusukan. Pada suhu dingin, khamir dan kapang mampu bertahan, pertumbuhannya berlangsung lambat dibandingkan pertumbuhan bakteri lainnya. Pengecualian terjadi jika faktor lingkungan dikontrol sehingga menghambat pertumbuhannya. Khamir dapat menyebabkan masalah kerusakan apabila pertumbuhan bakteri dikontrol atau dibatasi. Banyak khamir yang dapat tumbuh dalam kondisi tanpa oksigen dalam atmosfer terkontrol, diantaranya Candida spp., Kluveromyces spp., dan Saccharomyces spp. Sedangkan jenis kapang perusak yang umumnya mempengaruhi produk dingin yaitu Aspergillus spp., Cladosporium spp., Geotrichum spp., Penicillium spp., Phytophthora, Altenaria, Botrytis, Aspergillus, dan Rhizopus spp. Buah dan sayur merupakan salah satu pangan segar dengan olahan suhu rendah yang rentan terhadap keberadaan mikroorganisme tersebut (Dilbaghi dan Sharma, 2007).

Saat ini diketahui beberapa jenis spesies bakteri pathogen ternyata dapat tumbuh dengan baik pada suhu dingin, bahkan dapat mencapai jumlah yang besar hingga cukup mematikan untuk menyebabkan keracunan setelah dikonsumsi walaupun dalam jumlah beberapa sel saja. Bakteri patogen ini meliputi Listeria monocytogenes (MGT=$\left.0,4^{\circ} \mathrm{C}\right)$, Clostridium botulinum tipe B dan $\mathrm{F}$ (pertumbuhan dan produksi toksin 3,3$5^{\circ} \mathrm{C}$ ), Aeromonas hydrophilia $(\mathrm{MGT}=-0,1-$ $1,2^{\circ} \mathrm{C}$ ), Yersinia enterocolitica (MGT=$\left.1,3^{\circ} \mathrm{C}\right)$, dan beberapa galur Bacillus cereus 
(MGT $=1^{\circ} \mathrm{C}$ untuk pertumbuhan sel dan $4^{\circ} \mathrm{C}$ untuk produksi toksin). Bakteri patogen lainnya tidak mampu tumbuh pada suhu dibawah $5^{\circ} \mathrm{C}$, namun dapat tumbuh jika terjadi penyalahgunaan suhu dan kemudian berlangsung lama dalam bahan pangan. Bakteri ini meliputi Salmonella sp. $\left(\mathrm{MGT}=5,1^{\circ} \mathrm{C}\right)$, Escherichia coli enteropatogenik (MGT $\left.=7,1^{\circ} \mathrm{C}\right)$, Vibrio parahaemolyticus dan Campylobacter sp. $\quad\left(\mathrm{MGT}=>10^{\circ} \mathrm{C}\right)$ (Fellows, 2006).

\section{Mikroorganisme dalam pangan olahan fermentasi}

Fermentasi dimanfaatkan untuk mengubah bahan organik yang terkandung dalam bahan pangan menjadi bentuk lain yang memiliki manfaat dan nilai tambah dengan bantuan mikroorganisme. Mikroorganisme memiliki kemampuan menghasilkan senyawa metabolit primer dan metabolit sekunder dalam kondisi lingkungan yang dikontrol. Fermentasi bertujuan untuk mengawetkan bahan pangan, khususnya pangan yang mudah rusak dan bersifat musiman. Aktivitas enzimatis mikroba akan memecah komponen pangan selama proses fermentasi. Enzim amilase, protease dan lipase yang terdapat dalam mikroba akan menghidrolisis komponen pangan menjadi komponen yang lebih sederhana seperti asam, alkohol, karbondioksida, peptide, asam amino, asam lemak dan komponen lainnya.

Fermentasi secara biokimia dapat diartikan sebagai metabolisme yang berlangsung anaerob (kondisi tidak membutuhkan oksigen), yaitu proses pemecahan bahan organik, khususnya glukosa dan bahan organik lainnya, baik bertindak sebagai donor elektron maupun akseptor elektron dan sejumlah energi dalam bentuk ATP akan dihasilkan pada proses ini. Beberapa bakteri yang bersifat anaerob fakultatif mampu melakukan proses fermentasi tanpa ketersediaan oksigen yang berfungsi sebagai akseptor electron. Fermentasi dari sudut industri mikrobiologi diartikan sebagai semua proses yang melibatkan penggunaan mikroba di dalamnya dalam skala besar tanpa memperhatikan proses biokimia yang terjadi pada mikroba itu sendiri.

Mikroorganisme memiliki peran dalam sangat penting dalam proses fermentasi karena memiliki enzim yang dibutuhkan. Mikroorganisme yang digunakan menentukan produk akhir yang dihasilkan, baik yang berupa produk kimianya maupun produk komersialnya. Perbedaan ini menjadi penciri identifikasi dari mikroba tersebut. Produk kimia yang dihasilkan dari proses fermentasi diantaranya asam laktat (Steptococcus, Lactobacillus), alcohol (Zymomonas, Saccharomyces), asam propionate (Propionibacterium), 2,3-butanediol (Enterobacter, Serratia, Bacillus) dan asam butirat (Clostridium) (Harley \& Prescott, 2002). Produk komersial yang dihasilkan dari fermentasi diantaranya tempe (Rhizopus oryzae), tape (Chlamydomucor oryzae, Endomycopsis burtonii), cider/sari buah (Saccharomyces cerevisiae) (Fellows, 2006).

Sekitar $80 \%$ pangan hasil fermentasi dihasilkan dari proses fermentasi yang berlangsung secra alami. Selama proses berlangsung dimungkinkan mengandung mikroorganisme fungsional, nonfungsional, dan bahkan yang bersifat pathogen. Bakteria pathogen yang umumnya ditemui pada pangan olahan fermentasi salah satunya adalah Yersinia enterocolitica, Bacillus cereus, Clostridium botulinum (Lindqvist and Lindblad dalam Tamang et. al, 2015).

\section{KESIMPULAN}

Keberadaan

mikroorganisme memiliki peranan yang penting, baik yang sifatnya mampu meningkatan mutu bahan pangan maupun yang patogen. Prosedur cara pengolahan yang baik (good 
manufacturing practices, GMP) sesuai standar HACCP selama proses pengolahan pangan mampu mengurangi cemaran mikroorganisme pathogen demi tercapainya keamanan pangan.

\section{DAFTAR PUSTAKA}

Brennan, James G. 2006. Food Processing Handbook. Weinheim: Wiley-VCH Verlag GmbH \& Co.KGaA.

Dilbaghi, N dan Sharma, S. 2007. Food and Industrial Microbiology. Hisar: University of Science and Technology.

Fellows, P.J. 2016. Teknologi Pengolahan Pangan: Prinsip dan Praktik. Jakarta: Penerbit Buku Kedokteran EGC.

Haberl-Meglic, S., et.al. 2016. The Effect of Temperature and Bacterial Growth Phase on Protein Extraction by Means of Electroporation. Biochemistry112: 77-82.
Gustiani, Erni. 2009. Pengendalian Cemaran Mikroba Pada Bahan Pangan Asala Ternak (Daging dan Susu) Mulai Dari Peternakan sampai Dihidangkan. Jurnal Litbang Pertanian. 28 (3).

Rawat, Seema. 2015. Food Spoilage: Microorganisms and their preventation. Asian Journal of Plant Science and Research. 5 (4).

Tamang, J. P. et. al. 2015. Microorganisms in Fermented Foods and Beverages. ResearchGate. Diakses 10 November 2018.

Wulandari, A., dkk. 2017. Angka Cemaran Mikroba dan Identifikasi Faktor Resiko Pada Tahap Pembersihan dan Perebusan Produksi Ikan Kayu di Kecamatan Kuta Alam, Kota Banda Aceh. Jimvet. 01 (2). 